\title{
Effect of Human Growth Hormone in Kwashiorkor and Marasmus
}

\author{
DAVID R. HADDEN and INGRID H. E. RUTISHAUSER \\ From the Medical Research Council Infantile Malnutrition Unit, Mulago Hospital, Kampala, Uganda
}

A cardinal feature of malnutrition in children is impairment of growth. Stunting occurs whether the primary dietary deficiency is of protein (kwashiorkor) or of total food (marasmus). The growth defect may persist for a long time after adequate nutrition is provided, and it has been suggested that part of this failure is related to a pituitary deficiency, secondary to the malnutrition. Purified human pituitary growth hormone $(\mathrm{HGH})$ is now available in small quantities, and the present study was undertaken to assess the effect of shortterm treatment with this preparation during the early days of dietary treatment. This is part of a larger study of endocrine interrelationships in human malnutrition.

\section{Patients and Experimental Procedure}

Effect of daily HGH during the second week of treatment. Balance studies were carried out on 11 children with established kwashiorkor and 8 with marasmus who were admitted to the Medical Research Council Infantile Malnutrition Unit in Kampala. The patients were selected by the clinical and biochemical parameters published elsewhere (Dean and Schwartz, 1953; Rutishauser, 1965). All were considerably undernourished. The cases of kwashiorkor had pitting oedema of the legs and some degree of hair change, in general related to weaning on to a protein-poor diet of matoke banana. The marasmic children had neither of these signs but showed extensive wasting of subcutaneous fat, usually following the failure of lactation in the mother, or her death.

Four children with kwashiorkor and four with marasmus received $\mathrm{HGH}$ during the second week of study (groups A and C). Seven with kwashiorkor and four with marasmus acted as controls (groups B and D) and were matched as far as possible with the children in the HGH groups. All the children received the appropriate dietary therapy used in this unit. The HGH groups in addition received $0.2 \mathrm{mg}$. $/ \mathrm{kg}$. $\mathrm{HGH}$ intramuscularly daily from the seventh to the fourteenth day. (HGH preparation R9, kindly supplied by the Medical Research Council Clinical Endocrinology Committee.)

Received June 29, 1966.
Children diagnosed as cases of kwashiorkor were given a diet of Casilan $\star$, dried skimmed milk, ccttonseed oil, and sugar (Dean and Swanne, 1963), providing $4 \mathrm{~g}$. protein and 93 calories $/ \mathbf{k g}$./day. In addition, these children were allowed cooked bananas as their appetite improved. Children with marasmus were given a diet of similar composition but containing extra cottonseed oil and some dextrose, at a level providing $7 \cdot 6 \mathrm{~g}$. protein and 200 calories $/ \mathrm{kg}$. day. All children received a multiple vitamin supplement, with folic acid $5 \mathrm{mg}$. for the first seven days of treatment, and cytamen $50 \mu \mathrm{g}$. for the first three days.

Clinical and biochemical measurements (Table I) were recorded on the first and fourteenth days of treatment, using techniques previously published from this Unit. The serum amino acid ratio (Whitehead, 1964) represents a convenient ratio of some non-essential amino acids (glycine, serine, glutamine) to the essential, branched-chain acids, leucine, isoleucine, valine, and methionine, and is normally less than 2.0 in wellnourished children in this community. The urinary hydroxyproline index (Whitehead, 1965) is the ratio of hydroxyproline to creatinine adjusted for body weight in random urine samples, and is of the order of 3.0 in healthy children. The total protein concentration in the serum was determined by the copper sulphate specific gravity method, the free fatty acids in the plasma by the method of Trout, Estes, and Friedberg (1960), and blood glucose by a glucose oxidase technique (Marks, 1959).

Nitrogen balance was carried out in the latter half of the second week of treatment and was continued for four consecutive 24-hour periods. In two children who became pyrexial in the third and fourth periods, the balance had to be discontinued. At the beginning of the balance period each child had been receiving the same diet for a period of at least $\mathbf{1 0}$ days. For the balance period the children were placed on a 'metabolic' bed. Urine was collected from boys by means of urine collectors and from girls by Coloplast $\dagger$ colostomy bags fitted with a tube at one corner. Urine was pooled and analysed in 24-hour periods. Faeces were collected into polythene storage containers as soon as seen. A carmine marker was given at the beginning and end of the balance

* Casilan-Calcium caseinate, Glaxo Laboratories Ltd.

† Coloplast-Distributed by Henleys Medical Supplies Ltd. 
period, and all stools were collected from the time of appearance of the first marker until the appearance of the second marker, bulked, and stored at $-20^{\circ} \mathrm{C}$. for analysis. Nitrogen was determined by a microKjeldahl method.

Effect of a single large dose of HGH on free fatty acid mobilization in kwashiorkor. Seven other children with acute kwashiorkor (group E) were given a single dose of $5 \mathrm{mg}$. $\mathrm{HGH}$ (equivalent to $0.7 \mathrm{mg}$. $/ \mathrm{kg}$.) on the day of admission, before any dietary protein had been received, and after at least six hours of total fast. Venous blood was collected from the internal jugular vein at hourly intervals for four hours, and glucose and free fatty acids were determined.

\section{Results}

Table I shows that the children with kwashiorkor (groups A and B) were older than those with marasmus (groups $\mathrm{C}$ and $\mathrm{D}$ ), their weight was nearer that to be expected from their age, and they had a reasonable amount of subcutaneous fat. The mean serum total protein was low (normal $>6.0 \mathrm{~g}$. $100 \mathrm{ml}$.), the serum amino acid ratio raised, and the urinary hydroxyproline index decreased. Mean fasting blood glucose was below that found by
Whitehead and Harland (1967) in well-nourished ('elite') children in Kampala, and the mean plasma free fatty acid was raised. The children with marasmus, who were younger, had a much more severe weight deficit $(<50 \%$ expected weight for age), and severe loss of subcutaneous fat. The mean serum protein concentration was normal, the mean amino acid ratio was only minimally above normal, but the urinary hydroxyproline index was considerably decreased. The levels of blood glucose resembled those found in the children with kwashiorkor but the free fatty acids were not raised.

After treatment for 2 weeks all the children showed good clinical improvement: there was no objective difference between those who received HGH and those who served as controls. Table II shows the changes in the clinical and biochemical findings. Statistical analysis of the mean change in each group is of limited value in most instances because of the wide scatter and the small number of individual values. There was improvement in all instances over the value on admission, but in only two was there a significant difference $(p<0.05)$ between a control group and that receiving $\mathrm{HGH}$. In both of these (rise in serum protein in kwashiorkor and rise in urinary hydroxyproline in marasmus) the

TABLE I

Clinical and Biochemical Observations in Children with Kwashiorkor and Marasmus Before Start of Treatment (mean \pm standard deviation)

\begin{tabular}{|c|c|c|c|c|c|c|c|c|c|c|}
\hline Group & No. & $\underset{\text { (mth.) }}{\text { Age }}$ & $\begin{array}{c}\text { Weight } \\
\text { (kg.) }\end{array}$ & $\begin{array}{c}\% \\
\text { Expected } \\
\text { Weight } \\
\text { for Age }\end{array}$ & $\begin{array}{c}\text { Skinfold } \\
\text { Thickness } \\
\text { (triceps) } \\
\text { (mm.) }\end{array}$ & $\begin{array}{c}\text { Serum } \\
\text { Protein } \\
\text { (g./100 } \\
\text { ml.) }\end{array}$ & $\begin{array}{c}\text { Serum } \\
\text { Amino } \\
\text { Acid } \\
\text { Ratio }\end{array}$ & $\begin{array}{c}\text { Urinary } \\
\text { Hydroxy- } \\
\text { proline } \\
\text { Index }\end{array}$ & $\begin{array}{c}\text { Blood } \\
\text { Glucose } \\
\text { (mg./100 } \\
\text { ml.) }\end{array}$ & $\begin{array}{c}\text { Plasma } \\
\text { Free Fatty } \\
\text { Acid } \\
(\mathrm{mEq} / \mathrm{l} .)\end{array}$ \\
\hline $\begin{array}{l}\text { Kwashiorkor } \\
\text { (A and B) } \\
\text { Marasmus } \\
(C \text { and } D)\end{array}$ & $\begin{array}{r}11 \\
8\end{array}$ & $\begin{array}{r}20 \\
\pm 4 \\
+9 \\
\pm 8\end{array}$ & $\begin{array}{r}7 \cdot 28 \\
\pm 1 \cdot 61 \\
3 \cdot 88 \\
\pm 1 \cdot 16\end{array}$ & $\begin{array}{r}65 \cdot 3 \\
+11 \cdot 7 \\
44 \cdot 6 \\
\pm 6.9\end{array}$ & $\begin{array}{r}7 \cdot 3 \\
\pm 1 \cdot 8 \\
3 \cdot 2 \\
\pm 1 \cdot 3\end{array}$ & $\begin{array}{r}4.4 \\
\pm 0.5 \\
6 \cdot 0 \\
\pm 0.7\end{array}$ & $\begin{array}{r}5 \cdot 35 \\
\pm 2 \cdot 18 \\
2 \cdot 40 \\
\pm 1 \cdot 08\end{array}$ & $\begin{array}{r}0.99 \\
\pm 0.33 \\
0.72 \\
\pm 0.39\end{array}$ & $\begin{array}{r}54 \cdot 3 \\
+15 \cdot 0 \\
52 \cdot 0 \\
\pm 16 \cdot 3\end{array}$ & $\begin{array}{r}1.07 \\
\pm 0.37 \\
0.79 \\
\pm 0.52\end{array}$ \\
\hline
\end{tabular}

TABLE II

Clinical and Biochemical Changes after Treatment for Two Weeks (mean and standard deviation)

\begin{tabular}{|c|c|c|c|c|c|c|c|c|}
\hline Group & No. & $\underset{\left(\mathrm{kg} \cdot{ }^{\star}\right)}{\text { Gain in }}$ & $\begin{array}{c}\text { Gain in } \\
\text { Skinfold } \\
\text { Thickness } \\
\left(\mathrm{mm} .^{\star}\right)\end{array}$ & $\begin{array}{c}\text { Rise in } \\
\text { Serum } \\
\text { Protein } \\
\text { (g./100 ml.) }\end{array}$ & $\begin{array}{c}\text { Fall in } \\
\text { Amino } \\
\text { Acid Ratio }\end{array}$ & $\begin{array}{c}\text { Rise in } \\
\text { Hydroxy- } \\
\text { proline } \\
\text { Index }\end{array}$ & $\begin{array}{c}\text { Change in } \\
\text { Blood } \\
\text { Glucose } \\
\text { (mg. } / 100 \mathrm{ml} .)\end{array}$ & $\begin{array}{c}\text { Change in } \\
\text { Plasma } \\
\text { Free Fatty } \\
\text { Acid (mEq/1.) }\end{array}$ \\
\hline $\begin{array}{l}\text { A Kwashiorkor } \\
\text { Standard treatment } \\
\text { B Kwashiorkor } \\
\text { Standard treatment } \\
\text { plus HGH } \\
\text { C Marasmus } \\
\text { Standard treatment } \\
\text { D Marasmus } \\
\text { Standard treatment } \\
\text { plus HGH }\end{array}$ & $\begin{array}{l}7 \\
4 \\
4 \\
4\end{array}$ & $\begin{array}{l}0.73 \\
\pm 0.59 \\
0.95 \\
\pm 0.32 \\
\mathbf{p}>0.5 \\
0.71 \\
\pm 0.12 \\
0.47 \\
\pm 0.27 \\
\mathbf{p}>0.3\end{array}$ & $\begin{array}{rl} & 0.80 \\
\pm & 0.69 \\
1.23 \\
\pm & 0.17 \\
\mathbf{p} & 0.3 \\
0.65 \\
\pm 1.09 \\
2.30 \\
\pm 1.23 \\
\mathbf{p}>0.05\end{array}$ & $\begin{array}{r}2.73 \\
\pm 0.49 \\
1.60 \\
\pm 0.54 \\
\mathbf{p}>0.01 \\
1.40 \\
\pm 0.24 \\
0.55 \\
\pm 0.69 \\
\mathbf{p}>0.05\end{array}$ & $\begin{array}{ll} & 3 \cdot 16 \\
\pm & 2.49 \\
5.02 \\
\pm & 0.95 \\
\mathbf{p} & 0.2 \\
& 0.02 \\
\pm & 1.91 \\
& 1.00 \\
\pm & 2 \cdot 11 \\
\text { p } & 0.5\end{array}$ & $\begin{aligned} 0.85 \\
\pm 0.53 \\
0.84 \\
\pm 0.76 \\
\mathbf{p}>0.9 \\
0.89 \\
\pm 0.40 \\
0.32 \\
\pm 0.20 \\
\text { p }>0.02\end{aligned}$ & $\begin{array}{r}3.3 \\
\pm 24 \cdot 7 \\
\pm 10.0 \\
\pm 24 \cdot 6 \\
\mathrm{p}>0.3 \\
4.3 \\
\pm 17.9 \\
-4.3 \\
\pm 10.4 \\
\mathrm{p}>0.4\end{array}$ & $\begin{array}{r}-0.22 \\
\pm 0.05 \\
\pm 0.46 \\
\pm 0.26 \\
\mathbf{p} 0.05 \\
-0.03 \\
\pm 0.45 \\
\pm 0.16 \\
\pm 0.89 \\
\text { p }>0.6\end{array}$ \\
\hline
\end{tabular}

Note: The probability $\mathrm{p}$ of the standard deviation of the differences between the means in each column for groups (A) and (B), and for groups (C) and (D), was calculated from individual ' $t$ ' tests.

$\star$ Measured at the time of discharge, approximately three weeks after admission.

+ One ratio was obtained after three weeks instead of two. 
control group was superior. These differences are most probably related to poor matching of the values on admission in these particular criteria. Differences approaching significance $(0.1>p>0.05)$ are shown for the HGH treated groups in respect of the fall in plasma free fatty acids in kwashiorkor, and the increase in subcutaneous fat and serum protein in marasmus. There is nevertheless no consistent trend in favour of the HGH treated groups in either type of malnutrition.

These essentially negative results are confirmed by the nitrogen balance data (Table III). There was no fall in absolute urinary nitrogen due to HGH treatment, or any change in percentage nitrogen absorption or retention ( $p>0.05$ in all instances). The lower mean dietary nitrogen intake in groups $B$ and $D$ compared with $\mathrm{A}$ and $\mathrm{C}$, respectively (significant in group $\mathrm{B}, \mathrm{p}<0.001$ ), is again due to difficulties in complete cross-matching of patients: these groups ate rather less throughout the study. These differences have affected the calculation of the nitrogen absorption and retention, and result in the significantly lower figure for the absolute nitrogen absorption in group $B(0.05>p>0.01)$. However, as both groups $B$ and $D$ had in fact a slightly higher urinary excretion of nitrogen than their controls, it is unlikely that any effect of $\mathrm{HGH}$ in reducing nitrogen excretion was being obscured.

Table IV shows the levels of plasma free fatty acids and blood glucose in the seven acute cases of kwashiorkor which received a single dose of $5 \mathrm{mg}$. $\mathrm{HGH}$ in the fasting state. (The mean serum protein in this group was $4.6 \mathrm{~g} . / 100 \mathrm{ml}$., mean serum amino acid ratio 4.93 , and urinary hydroxyproline index 1.71.) There was no significant change in free fatty acids or glucose in the following four-hour period whether the fasting levels of free fatty acids were normal or already raised. The same preparation of $\mathrm{HGH}$ raised the free fatty acids in a fasting normal adult (dose level $0.14 \mathrm{mg} . / \mathrm{kg}$., total dose $10 \mathrm{mg}$.) from $0 \cdot 78$ to $2 \cdot 21 \mathrm{mEq} / \mathrm{l}$. within four hours.

\section{Discussion}

The preparation of human growth hormone used in the present study was shown to be active by the

TABLE III

Nitrogen Balance Data (days 10-14) (means and standard deviation: probabilities as in Table II)

\begin{tabular}{|c|c|c|c|c|c|c|c|}
\hline \multirow{2}{*}{ Group } & \multirow{2}{*}{ 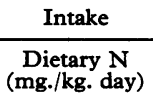 } & \multicolumn{2}{|c|}{ Excretion } & \multirow{2}{*}{$\frac{\text { Absorption }}{\mathrm{N}}$} & \multirow{2}{*}{$\frac{\text { Retention }}{\text { (mg./kg. day) }}$} & \multirow{2}{*}{$\begin{array}{c}\text { Absorption } \\
\text { as \% of } \\
\text { Intake }\end{array}$} & \multirow{2}{*}{$\begin{array}{l}\text { Retention } \\
\text { as \% of } \\
\text { Absorption }\end{array}$} \\
\hline & & $\underset{\text { (mg./kg. day) }}{\text { Urinary N }}$ & $\begin{array}{c}\text { Faecal N } \\
\text { (mg./kg. day) }\end{array}$ & & & & \\
\hline $\begin{array}{l}\text { A Kwashiorkor } \\
\text { Standard treatment } \\
\text { B Kwashiorkor } \\
\text { Standard treatment } \\
\text { plus HGH } \\
\text { C Marasmus } \\
\text { Standard treatment } \\
\text { D Marasmus } \\
\text { Standard treatment } \\
\text { plus HGH }\end{array}$ & $\begin{array}{c}684 \\
\pm 21 \\
615 \\
\pm 23 \\
\mathrm{p}<0.001 \\
1231 \\
\pm 144 \\
1133 \\
\pm 49 \\
\mathrm{p}>0.2\end{array}$ & $\begin{array}{c}279 \\
\pm 6 \\
281 \\
\pm 47 \\
p>0.9 \\
501 \\
\pm 243 \\
509 \\
\pm 31 \\
p>0.9\end{array}$ & $\begin{array}{c}110 \\
\pm 39 \\
107 \\
\pm 20 \\
\mathrm{p}>0 \cdot 8 \\
120 \\
\pm 61 \\
122 \\
\pm 20 \\
\mathrm{p}>0.9\end{array}$ & $\begin{array}{c}572 \\
\pm 49 \\
508 \\
\pm 17 \\
\mathrm{p}<0.05 \\
1110 \\
\pm 144 \\
1011 \\
\pm 38 \\
\mathrm{p}>0.2\end{array}$ & $\begin{array}{c}294 \\
\pm 30 \\
228 \\
\pm 48 \\
p>0.05 \\
610 \\
\pm 128 \\
502 \\
\pm 43 \\
p>0.1\end{array}$ & $\begin{array}{r}84 \cdot 0 \\
\pm 5 \cdot 4 \\
82 \cdot 8 \\
\pm 2 \cdot 6 \\
p>0 \cdot 6 \\
90 \cdot 3 \\
\pm 5 \cdot 1 \\
89 \cdot 3 \\
\pm 1 \cdot 5 \\
p>0 \cdot 7\end{array}$ & $\begin{array}{r}51 \cdot 4 \\
\pm 9 \cdot 2 \\
44 \cdot 5 \\
\pm 9 \cdot 6 \\
\mathrm{p}>0 \cdot 2 \\
56 \cdot 3 \\
\pm 14 \cdot 9 \\
49 \cdot 8 \\
\pm 2 \cdot 2 \\
\mathrm{p}>0.4\end{array}$ \\
\hline
\end{tabular}

TABLE IV

Effect of 5 mg. Human Growth Hormone on Fasting Glucose and Free Fatty Acid Levels in Untreated Kwashiorkor (group E)

\begin{tabular}{|c|c|c|c|c|c|c|c|c|c|c|}
\hline \multirow{2}{*}{ Hours } & \multicolumn{5}{|c|}{ Plasma Free Fatty Acid (mEq/1.) } & \multicolumn{5}{|c|}{ Blood Glucose (mg./100 ml.) } \\
\hline & 0 & 1 & 2 & 3 & 4 & 0 & 1 & 2 & 3 & 4 \\
\hline $\begin{array}{c}\text { Patients } \\
1 \\
2 \\
3 \\
4 \\
5 \\
6 \\
7\end{array}$ & $\begin{array}{l}0.62 \\
0.62 \\
0.78 \\
0.73 \\
0.89 \\
1.00 \\
1.46\end{array}$ & $\begin{array}{l}0.56 \\
0.59 \\
0.59 \\
0.68 \\
0.95 \\
1.11 \\
0.81\end{array}$ & $\begin{array}{l}0.46 \\
0.64 \\
0.65 \\
0.76 \\
0.95 \\
1.24 \\
1.40\end{array}$ & $\begin{array}{l}0.54 \\
0.59 \\
0.68 \\
0.76 \\
1 \cdot 11 \\
1.11 \\
1.91\end{array}$ & $\begin{array}{l}\overline{0} \overline{70} \\
\overline{0 \cdot 89} \\
1 \cdot 16 \\
1 \cdot 16 \\
-\end{array}$ & $\begin{array}{l}74 \\
62 \\
67 \\
42 \\
75 \\
65 \\
70\end{array}$ & $\begin{array}{r}69 \\
69 \\
66 \\
44 \\
100 \\
63 \\
54\end{array}$ & $\begin{array}{r}58 \\
68 \\
79 \\
28 \\
103 \\
59 \\
50\end{array}$ & $\begin{array}{r}49 \\
60 \\
57 \\
33 \\
103 \\
82 \\
47\end{array}$ & $\begin{array}{r}70 \\
30 \\
109 \\
69 \\
\end{array}$ \\
\hline Mean & $0 \cdot 87$ & $0 \cdot 75$ & $0 \cdot 87$ & 0.90 & 0.98 & 65 & 66 & 64 & 62 & 69 \\
\hline $\begin{array}{l}\text { Normal } \\
\text { control }\end{array}$ & $0 \cdot 78$ & 0.89 & $1 \cdot 24$ & $1 \cdot 00$ & $2 \cdot 21$ & 97 & 71 & 75 & 75 & 76 \\
\hline
\end{tabular}


effect of an equivalent dose in a normal adult on free fatty acid mobilization (Raben, 1959). The absence of demonstrable effect in either kwashiorkor or marasmus could then have been due to any of several causes.

(1) It is debatable whether any of the metabolic changes measured above would be sufficiently sensitive to show a response to HGH in the short time of this study, especially since the metabolic pattern was already changing rapidly in response to protein repletion alone. However, by choosing a wide range of observations it was hoped that an over-all trend might become apparent in terms of the known effects of $\mathrm{HGH}$ in increasing protein metabolism (gain in weight and rise in serum proteins), stimulating collagen turnover (rise in urinary hydroxyproline excretion), or mobilizing otherwise unavailable subcutaneous fat stores to provide energy as circulating free fatty acids.

(2) The most generally accepted index of $\mathrm{HGH}$ action on protein metabolism is a fall in urinary nitrogen. It is possible that the dose used $(0.2 \mathrm{mg}$./ $\mathrm{kg}$. day) was too low to produce such an effect in infants. Mönckeberg, Donoso, Oxman, Pak, and Meneghello (1963) showed a mean fall in urine nitrogen of $22.0 \mathrm{mg}$. $/ \mathrm{kg}$. day in six malnourished infants (mean age 7 months), representing $12.4 \%$ nitrogen retention, after a single dose of $\mathrm{HGH}$ equivalent to $0.14 \mathrm{mg} . / \mathrm{kg}$. day. Chiumello, Vaccari, and Sereni (1965) reported a mean fall in urine nitrogen of $30.0 \mathrm{mg} . / \mathrm{kg}$. day in four premature infants, or $5.1 \%$ nitrogen retention, after seven doses of $0.5 \mathrm{mg} . / \mathrm{kg}$. day, but these workers found no other demonstrable metabolic effect. Ducharme and Grumbach (1961), however, were unable to obtain any significant fall in blood urea nitrogen in premature infants until the dose reached $5 \mathrm{mg}$. $/ \mathrm{kg}$. day, and Vest, Girard, and Bühler (1963) considered that, while the qualitative response of nitrogen retention was similar in adults and normal children, the degree of response was less in the latter. None of these studies showed an effect on nitrogen retention at all comparable to that found in known cases of hypopituitary dwarfism. Hubble (1966), and R. Fraser (1966, personal communication), using dose levels of approximately $0.4 \mathrm{mg} . / \mathrm{kg}$. day in older children with established hypopituitarism, have demonstrated a fall in urinary nitrogen of the order of $100 \mathrm{mg}$. $/ \mathrm{kg}$. day (or up to $40 \%$ nitrogen retention) but not more than $20 \mathrm{mg}$. $/ \mathrm{kg}$. day in nonhypopituitary dwarfs of the same age. Prader, Illig, Széky, and Wagner (1964) had shown almost similar results (up to $55 \mathrm{mg}$. $/ \mathrm{kg}$. day fall with $38 \%$ nitrogen retention) in hypopituitary dwarfs, using a much smaller dose of growth hormone $(0.05 \mathrm{mg}$. $/ \mathrm{kg}$. day). It appears probable that the dosage used in the present study would have been sufficient to produce a striking effect if the condition had been truly comparable to primary hypopituitarism. The magnitude of the nitrogen retention found by other workers in non-hypopituitary subjects may be a function of the size of the dose.

(3) The levels of nitrogen intake were much higher (range $600-1200 \mathrm{mg} . / \mathrm{kg}$. day) in the present study than in those cited on hypopituitary dwarfs (range $200-300 \mathrm{mg} . / \mathrm{kg}$. day), but our patients were retaining only between 51 and $56 \%$ of absorbed nitrogen and there should have been room for improvement if $\mathrm{HGH}$ had a significant effect. Schendel and Hansen (1965) found that in their cases of kwashiorkor, nitrogen retention on free diet was greatest on the fifth day and subsequently fell regardless of the level of nitrogen intake. In the present study $\mathrm{HGH}$ was given during the second week when this fall might have been expected to become operative. Short-term balance studies of this type may not represent the whole picture, and it is possible that an effect might have been obtained had the treatment continued over a longer period.

(4) The inability of a relatively large single dose of HGH to mobilize free fatty acids in kwashiorkor may indicate 'end-organ' resistance in these children as the cause of their persistent failure to grow. A similar reason may explain why newborn prematures also fail to mobilize free fatty acids after $\mathrm{HGH}$ (Ducharme and Grumbach, 1961; Chiumello et al., 1965), and why HGH is ineffective during the acute phase of the metabolic response to trauma (Johnston and Hadden, 1963). It is hoped to obtain more evidence on this point and on the distinctions between kwashiorkor and marasmus from serum growth hormone assays in these children, which will subsequently be reported in full.

\section{Summary}

Human growth hormone $0.2 \mathrm{mg}$. $/ \mathrm{kg}$. produced no significant metabolic effect in children with kwashiorkor or marasmus when given during the second week of dietary rehabilitation. A larger dose failed to mobilize free fatty acids before dietary treatment began.

We are grateful to Dr. R. G. Whitehead and to Professor R. A. McCance for their helpful criticism and advice. We are very appreciative of the nursing skill of Miss V. Jones, Miss S. Cook, Miss S. Healey, Miss S. James, and Miss M. Morris, nursing sisters in the unit, and of their attention to detail during the balance periods.

\section{REFERENCES}

Chiumello, G., Vaccari, A., and Sereni, F. (1965). Bone growth and metabolic studies of premature infants treated with human growth hormone. Pediatrics, 36, 836. 
Dean, R. F. A., and Schwartz, R. (1953). The serum chemistry in uncomplicated kwashiorkor. Brit. F. Nutr., 7, 131.

, and Swanne, J. (1963). Abbreviated schedule of treatment for severe kwashiorkor, May 1962. F. trop. Pediat., 8, 97.

Ducharme, J. R., and Grumbach, M. M. (1961). Studies on the effects of human growth hormone in premature infants. 7 . clin. Invest., 40, 243.

Hubble, D. (1966). Studies with human growth hormone. Arch. Dis. Childh., 41, 17.

Johnston, I. D. A., and Hadden, D. R. (1963). Effect of human growth hormone on the metabolic response to surgical trauma. Lancet, 1, 584.

Marks, V. (1959). An improved glucose-oxidase method for determining blood, C.S.F. and urine glucose levels. Clin. chim. Acta, 4, 395.

Mönckeberg, F., Donoso, G., Oxman, S., Pak, N., and Meneghello, J. (1963). Human growth hormone in infant malnutrition. Pediatrics, 31, 58.

Prader, A., Illig, R., Széky, J., and Wagner, H. (1964). The effect of human growth hormone in hypopituitary dwarfism. Arch. Dis. Childh., 39, 535.

Raben, M. S. (1959). Human growth hormone. Recent Progr. Hormone Res., 15, 71.

Rutishauser, I. H. E. (1965). Heights and weights of middle class Baganda children. Lancet, 2, 565.

Schendel, H. E., and Hansen, J. D. L. (1965). Daily urine nitrogen partition and balance in infants with kwashiorkor. Amer. $f$. clin. Nutr., 17, 36.

Trout, D. L., Estes, E. H., Jr., and Friedberg, S. J. (1960). Titration of free fatty acids of plasma: a study of current methods and a new modification. F. Lipid Res., 1, 199.

Vest, M., Girard, J., and Bühler, U. (1963). Metabolic effects of short term administration of human growth hormone in infancy and early childhood. Acta endocr. (Kbh.), 44, 613.

Whitehead, R. G. (1964). Rapid determination of some plasma aminoacids in subclinical kwashiorkor. Lancet, 1, 250.

- (1965). Hydroxyproline creatinine ratio as an index of nutritional status and rate of growth. ibid., 2, 567.

-, and Harland, P. S. E. G. (1967). Brit. F. Nutr. In the press. 